\title{
SECURITY, PERCEIVED SAFETY, AND EVENT ATTENDEE ENJOYMENT AT THE 2003 RUGBY WORLD CUP
}

\author{
TRACY TAYLOR* and KRISTINE TOOHEY†
}

*School of Business, University of Technology, Sydney, NSW, Australia

†Department of Tourism, Leisure, Hotel and Sport Management, Griffith University QLD, Australia

\begin{abstract}
International sport event organizers around the world have placed considerations of terrorism high on their planning and risk management agendas since September 11, 2001. Increased public awareness about the threat of terrorism and associated safety concerns have led to increased security, especially for large multicountry intemational events. To date there has been limited empirical research on the relationship between sport event attendance and the impact of terrorism, with the exception of the body of work on the 1972 Olympic Games. In this article the authors outline the extensive antiterrorism security measures taken at the 2003 Rugby World Cup held in Australia. To determine the impact of these measures, event attendees were surveyed to determine the extent to which terrorism influenced event attendees' motivations, perceptions of safety, and level of enjoyment. The results indicate that security measures were perceived as sufficient and attendees were generally not deterred by the threat of terrorism. The heightened security enhanced the event experience for some attendees, with only a small minority reporting a negative impact on satisfaction. Suggestions for further research and practice are discussed.
\end{abstract}

Key words: Sport event; Rugby World Cup; Mega-event; Terrorism; Security; Australia

\section{Introduction}

The impacts of mega-events and hallmark events tre typically measured on a multitude of indices inclading economic, tourism, commercial, physical, aciocultural, psychological, and political impacts Gaulkner \& Raybould, 1995). The influence of exWhal threats, such as terrorism on perceptions of cority for mega-sport event spectators, is an area of limited empirical investigation. To specifically explore the relationship between sport event attendance, terrorism, and spectators' enjoyment, a scoping study was undertaken of the International Rugby Board (IRB) Rugby World Cup (RWC) 2003, held in Australia. As major sport events have been touted as potential targets for terrorist activity (Toohey, Taylor, \& Lee, 2003) we wanted to explore how event organizers dealt with the increased secu- 
rity requirements and the reactions of the attendees to the security provided.

Since the late 1960 s, technological advances to the media, especially satellite transmissions, have provided terrorists and other protestors with a global realtime audience to publicize their message. Mega-sporting events, such as the Olympic Games and the FIFA World Cup, have become much more likely to be considered as terrorist targets due to this worldwide audience (Toohey et al., 2003). Tarlow (2002) catalogued a range of potential danger areas in the interface between mega-sporting events and terrorism, including: spectator numbers and flows, which make it difficult to physically identify terrorists; the proximity of events to transportation hubs, allowing a quick escape route; and the extensive use of event-associated hospitality sectors (e.g., hotels and restaurants) that also have the potential to be affected, spreading the reach and impact of an incident. The long-term economic effect of terrorism on sport events can be profound (Solberg \& Preuss, 2005). However, with the exception of the 1972 Munich Olympic Games, studies into the interrelationships that exist between sport events and terrorism are rare, despite the fact that sport has not been immune from terrorist activities (Wedermeyer, 1999).

As mega-sport events are typically aligned with tourism generation, the tourism-terrorism dimension has particular relevance. Sömnez (Coles, 2003) posited that the major themes that unite terrorism to tourism are "the impacts of terrorism and political instability on tourism; using tourism as a political tool to advance the terrorists' agenda; the effects of political and terrorist violence on destination imagery; crisis management and recovery marketing efforts" (p. 176) Furthermore, Richter and Waugh (1986) noted that tourists from regimes that are considered to be hostile may be targeted by terrorists because of their symbolic value. According to Guzman (Ryan, 1993), left wing terrorists have validated attacks on tourists because tourism is symbolic of capitalism; tourists generally are citizens of developed countries; and state-sponsored tourism is symbolic of the government that supports it.

Since September 11, $2001(9 / 11)$, the threat of terrorism has become an even greater planning priority for hotels, airports, sport events, and other places where sport tourists congregate (Goodrich, 2002). Additional preparation is an essential element of risk control, as when an act of tourist-related te rorism occurs the media will report it, compelling the event organizers to enact crisis management prot cedures (Cavleck, 2002; Tarlow, 2002). Moreover, Tarlow (2002) noted that perceptions about an event crisis can be almost as detrimental as the crisis itself, commenting that, "the farther away one is from a crisis location, the worse the crisis will appear to be and the longer the crisis will remain in the collective travel subconscious" (p. 2). Thus, diligence and safety concerns have led to event organizers commissioning increased security planning precautions, resulting in escalating costs for events (Pantera et al., 2003).

The immediate and subsequent response, of sport event organizers after 9/11 was to increase security measures to prevent terrorism activity and allay safety concerns of players and spectators. The level of security measures was determined by government, sporting bodies, event organizers, and stadia, in response to both security concerns and insurance requirements. However, as security increased so did queues to get into sport grounds; bag and body searches were undertaken, limitations were placed on items that spectators could take into stadiums, and spectator movements were restricted. By instigating more extensive security measures many sport event organizers were conscious of trying to attain an appropriate balance without negatively impacting on the spectator experience. As Frosdick (1997) noted, the management and operations of sport stadia should provide patrons with "pleasurable experiences in an enjoyable and safe way" (p. 4).

To ascertain how successful mega-sport events have been at achieving the optimal balance between security and attendee satisfaction, the situation of the 2003 RWC in Australia was investigated. Scoping provides the sport event management community with case study data to review, which can then be modified, accepted, or rejected for application to other situations. Responses and activities of the event planners and the impact of security measures on event attendees were interrogated. Data gathered encompassed government security reports, documentation from the official event organizer, newspaper articles, and a survey of event attendees.

The study follows on from similar work that was completed at the 2002 FIFA World Cup (Toohey et al., 2003). This study offers an approach for event 
managers to use in assessing their current and future vulnerability to disruption by terrorist threats. The findings also provide a basis for a full-scale study or planning process that major sport event organizers could use to address current and potential future security vulnerability.

\section{Terrorism and Mega-Sport Events}

It has been suggested that sport event tourists are especially likely to avoid a destination because of terrorism concerns (Solberg \& Preuss, 2005). This is in part as a function of the nature of mega-sports events; they are often held in stadia with enormous seating capacity; a mass of spectators are located in a concentrated area, and this could be deemed as a suitable terrorists' target due to the high level of visibility and vulnerability of the event and its attendees (Whisenant, 2003). Terrorism has a much greater psychologically negative effect on potential tourists than many other forms of disasters, including natural catastrophes (Cavlek, 2002). As Pizam and Mansfeld (1996) note, attendance at sport events, as a form of leisure tourism, is a discretionary activity. Furthermore, the tourism industry is extremely vulnerable to crises (Santana, 2003). Given the discretionary choice, it is plausible that many potential event goers may choose not to attend if there is a threat to their safety. Most event visitors, with the exception of allocentric adventurers, will expect a secure environment (Tarlow, 2002).

Post-9/11, this has meant that the perceived risk of terrorism has not only kept spectators away from sporting events, it has also altered the experience of spectators who opt to attend (Cashman, 2004; Toohey \& Taylor, 2005). While an array of reasons such as high ticket and accommodation prices and scheduling problems were put forward to explain the disappointing attendance figures in the initial days of competition at the Athens Olympic Games, the most commonly advanced theory related to safety fears associated with terrorism (Cashman, 2004). In Athens, a side effect of the intensified security measures was increased spectator queuing time, routine examinations with metal detectors, and frequent patdown searches. In this and other cases, sport event organizers have introduced an ever-growing array of restrictions on items that spectators can take into stadiums. Once inside, fans are now more closely monitored by both security personnel and electronic surveillance (Carey, 2004; Toohey et al., 2003; Whisenant, 2003).

The changes to security at major sport events after 9/11 were clearly evident at the 2002 Salt Lake City Winter Olympic Games. Salt Lake City was the largest city, with approximately 1.5 million people, to host a Winter Olympic Games and the event was the largest Winter Olympic Games to date, with 3,500 Olympic athletes, 70 sporting events, and 10 Venues (United States General Accounting Office, 2001). Soon after the $9 / 11$ tragedy there was a reevaluation of the event's security procedures (Diaz, 2001). A press statement released by the White House outlined the new approach to Games security as "highly visible equals highly secure" (United States Office of the Press Secretary, 2002). As part of the associated strategy, airport security was increased and airspace restricted. The Organizing Committee acquired 15,000 antianthrax tablets and the Utah State government commissioned the design and implementation of health monitoring systems to detect and manage possible incidents of bioterrorism. Biometric scanners were used to identify accredited officials and athletes, and vehicles were prohibited within 300 feet of venues and other selected buildings. In total, there were 60 different federal, state, and local agencies, and over 15,000 people, including 10,000 national guardsmen, involved in Games-related security operations (Gesterland et al., 2003; Snider, 2002; Tsui et al., 2003). It is estimated that the $9 / 11$ attacks resulted in an additional US\$70 million spending on Games' security, bringing the total security budget to around US\$500 million (Snider, 2002). This amount was more than double that of the 1996 Atlanta Summer Olympics (Janofsky, cited in Wicks, 2002).

Cronin (2003) contends that terrorism attacks such as $9 / 11$ are a reaction to globalization, by those without power, and are also facilitated by globalization's trappings (e.g., by the Internet, mobile phone technology, and global financing). However, she also notes that globalization has also led to increased efficiencies in international responses and terrorism countermeasures through processes such as increasing international cooperation in matters of law enforcement, intelligence sharing, and tighter financial controls. The security planning for the 2003 RWC, an international event contested by countries 
from across the globe, held in Australia, was directly affected by the events of $9 / 11$. Whether or not increased efficiencies or a better spectator experience resulted from the extensive security measures is a key question in this study.

\section{Background and History of the RWC}

From its inception in 1987 the RWC has grown to be the world's third largest sporting event in terms of spectators and television audience (Australian Department of Industry, Tourism and Resources, 2004). It was the largest sporting event held in the nation since the 2000 Sydney Olympic Games.

The tournament follows a 4-year cycle, as do the other two most significant mega-sport events: the Olympic Games and the FIFA World Cup. The RWC is held the year after each FIFA World Cup and preceding each Summer Olympic Games. The 2003 RWC, staged from October 10 to November 22, was hosted by the Australian Rugby Union (ARU), in conjunction with the sport's governing body, the International Rugby Board (IRB). In terms of the tournament's governance, the ARU had responsibility for the event's organization and staging, while the IRB controlled the commercial aspects, such as broadcasting rights, sponsorship, and licensing. The economic impact was estimated to be close to $A \$ 1$ billion (Australian Department of Industry, Tourism and Resources, 2004; Australian Rugby Union, 2004).

There were $1,800,000$ spectators who watched RWC matches, resulting in ticket sales of almost A $\$ 200$ million. The Australian government esti- mated that 65,000 of these spectators were from overseas and had visited Australia primarily because of the RWC (Australian Department of Industry, Tourism and Resources, 2004). This assessment was based on figures sourced from the ARU and QANTAS (the official RWC airline carrier), the Australian Bureau of Tourism Research, and information collected during the event. Early estimates had predicted up to 75,000 international visitors would attend, mostly from New Zealand, the UK, and Europe. These calculations were revised down to 40,000 in mid-2003, because of lower than expected ticket package sales from overseas visitors and a number of non-event-related international travel issues, including an outbreak of the SARS virus in Asia and the war in Iraq (Australian Department of Industry, Tourism and Resources, 2004). An estimated breakdown of the countries of origin, type of international visitors, and their expenditure is presented in Table 1.

\section{Security and the RWC}

The threat of terrorism was considered to be a risk by the event organizers and the Australian government during the RWC. The administration recognition of the possible danger was essential, as only governments and the international community are successful in preventing terrorism (Pizam, 1999). The tournament was held only 2 years after $9 / 11$, in which 15 Australian nationals died, and 1 year after 88 Australians were killed and 100 injured by Islamic terrorist bombings in Bali. The Australian Department of Foreign Affairs and Trade (2003)

Table 1

Estimated International Visitors to RWC 2003 by Region and Economic Impact

\begin{tabular}{|c|c|c|c|c|c|c|}
\hline Region & Competing Countries & $\begin{array}{l}\text { Rugby } \\
\text { Supporters }\end{array}$ & Media & Corporate & Total & $\begin{array}{c}\text { Estimated Total } \\
\text { Trip Spend (\$A M) }\end{array}$ \\
\hline Europe & $\begin{array}{l}\text { England, France, Georgia Ireland, } \\
\text { Italy, Romania, Scotland, Wales }\end{array}$ & 28,200 & 1,094 & 2,500 & 31,794 & 256.1 \\
\hline $\begin{array}{l}\text { New Zealand/ } \\
\text { Asia Pacific }\end{array}$ & $\begin{array}{l}\text { New Zealand, Japan, Fiji, Hong Kong." } \\
\text { Samoa, Singapore," Tonga }\end{array}$ & 18,600 & 813 & none reported & 19,413 & 59.2 \\
\hline Africa & South Africa, Namibia & 10,200 & 438 & none reported & 10,638 & 64.5 \\
\hline Americas & Argentina, Canada, US, Uruguay & 3,000 & 155 & none reported & 3,155 & 20.6 \\
\hline Total & & 60,000 & 2,500 & 2,500 & 65,000 & 400.4 \\
\hline
\end{tabular}

Adapted from Australian Department of Industry, Tourism and Resources (2004, pp. 2-11, 3-12).

aHong Kong and Singapore, although not competing countries, were included in estimates of visitor numbers, as large numbers of expatriates from these countries traveled home to see the RWC. 
viewed these attacks as defining events, in terms of both the nation's foreign and domestic policies noting that "they have changed Australia's security environment in significant ways. They starkly demonstrated that threats to Australia's security can be global as well as regional.” The Bali attacks in particular signaled that there was a prospect of terrorism occurring in Australia itself. According to the Australian Department of Foreign Affairs and Trade's (2003) White Paper, "Advancing the National Interest," "Australia is committed to the international campaign to eliminate the global threat of terrorism because terrorism threatens Australians at home and overseas. Terrorist groups such as alQaeda and Jemaah Islamiyah attack our values" (p. 1).

The Australian obligation to combating terrorism meant that Australian troops joined the US-led invasion of Iraq. This move, itself divisive within the country, further influenced perceptions that the US and its allies, including Australia, were at even greater risk of terrorist attacks by Islamic extremists. As a result, the Australian, English, and US teams received added security during the RWC (Australian Broadcasting Commission, 2003).

Despite these concerns the RWC was only given an overall rating as a "low-risk" potential target for terrorists by some intelligence experts (Australian Broadcasting Commission, 2003). For example, either knowledgeably or naively, analyst Clive Williams said the tournament would be largely "off-radar for Islamic extremists, because few Muslim countries play rugby. ... "It's not the sort of thing that would attract them.... It's not something they would have looked at as a potential target" (Australian Broadcasting Commission, 2003). Notwithstanding such assessments, the organizers treated the event as a "medium risk," arguing that it would be easier to scale down security measures rather than scale them up in an emergency (Australian Broadcasting Commission, 2003). Security planning reflected this approach. As the games were played across Australia, the security planning required coordination between relevant local, state, and federal agencies. The model for RWC security, first developed for the Sydney 2000 Olympic Games, had also been adapted to suit other major international events hosted by Australia, such as the Commonwealth Heads of Government Meeting.
A World Cup security working group, headed by the Australian Attorney-General Department's Protective Security Coordination Centre (PSCC), coordinated the event's security planning. Also involved were the Australian Security and Intelligence Organisation (ASIO), the Australian Defence Force (ADF), and state and federal police (Metcalfe, 2004). According to Metcalfe (2004) the coordinated planning took place at three levels:

1. The Commonwealth Security Working Group, chaired by the PSCC, to ensure that Australian government preparations were coordinated and consistent with State/Territory preparations;

2. Policing and Security Working Group, comprising relevant Commonwealth agencies (PSCC, the Australian Federal Police, the Australian Defense Force, the Department of Industry, Tourism and Resources), Qantas, Sydney Airports Corporation Ltd, the Australian Rugby Union, and other host State police; and

3. Working groups for local planning purposes.

The ARU 2003 Annual Report (2004) noted that "venue security was appropriate for an international event ... even the large and boisterous crowds, who enjoyed imbibing, were well behaved, before, during and after the matches. This was commented on by all police forces, which allowed them to have a good time" (p. 54).

Managing sports stadia during events to ensure that they are safe and spectators can enjoy themselves is a complex problem (Frosdick, 1997). Since 9/11 this balance has become even more problematic. The RWC provided an example of sport event organizers investing substantially more than originally planned in security measures due to the increased threat of terrorism. At the same time they also had to ensure that the people traveling to watch and participate were not overwhelmed by the heightened security to the extent that it detracted from their experience. We assess here how successful the organizers were in achieving their goal, and how event attendees perceived the threat of terrorism and the relationships of these perceptions and the security measures taken.

The study aimed to document four aspects of terrorism and security at the RWC: (i) the measures taken to ensure appropriate levels of terrorism-re- 
lated security; (ii) spectators' perceptions of safety during the World Cup; (iii) the impact of the threat of terrorism on attendees' intentions to attend the event; and (iv) if risk management measures taken by the event organizers impacted on spectators' level of enjoyment.

\section{Method}

A sample of 511 World Cup attendees from the three New South Wales cities hosting matches (Sydney, Gosford, and Wollongong) were surveyed to determine: (a) the extent to which terrorism affected the attendees' motivations to attend the event; (b) how safe those attending matches felt during the World Cup; and (c) how risk management measures taken by the event organizers impacted on attendees' level of enjoyment. At the Wollongong and Gosford games, attendees were randomly surveyed just outside the venues before the game started. In Sydney, the survey was conducted on game days at the entrance to the Central Train Station and at the Darling Harbour live site. The train station was selected because the majority of attendees traveled by public transport to the matches at Olympic Stadium. The live site was relevant as the ARU and State and Territory governments organized an official program of entertainment, visual displays, and "live sites" where rugby fans could watch key matches. While not the most ideal locations, these sites were chosen due to International Rugby Board venue control protocols.

At fixed points at each location between two and five interviewers intercepted passing pedestrians, using the next available person technique. The potential respondent was informed of the survey's aim and invited to participate in the research. Upon approval to proceed, the respondents were initially screened by use of two questions that determined if they had attended, or were about to attend, any RWC games. If they answered yes to either of these two questions then the interviewer continued with the questionnaire.

The survey instrument incorporated items used to measure the perceptions of security for a 2002 FIFA World Cup study of spectators (Toohey et al., 2003). These security items were measured on a 5point Likert-type scale using a set of 10 items asking about their perceptions of the event. In addition, items on rugby involvement, taken from a study on rugby union fans by Ritchie, Mosedale, and King (2002), were added, along with key demographic questions. We also included three open-ended questions providing respondents the opportunity to write additional comments about security issues or safetyrelated suggestions for future events. The questions were "What were the principal reasons why you decided to come [to the RWC]?"; "Do you have any suggestions or comments about security measures that might help the organizers of future large sporting events?" and "Do you have any suggestions or comments about the impact of terrorist activities on sport?" The sample represented respondents from 19 countries. The majority of respondents resided in metropolitan Sydney. Table 2 presents data on respondents by region of residence.

\section{Results}

The 511 respondents reported attending two games on average, were mainly male $(73.4 \%)$, had a mean age of 32.2 years, were most likely to attend with a group of friends, and stayed an average of 9.2 nights in Sydney on RWC-related travel. Approximately $52 \%$ were active sport participants, $39.5 \%$ were members of a sport club, $42.5 \%$ were regular spectators at rugby matches, $12.3 \%$ had attended a previous Rugby World Cup event, and 6.7\% were season ticket holders for rugby. A further profile of respondents in provided in Table 3.

Respondents were asked to rate the importance of a range of items on their decision to come to the RWC using the 5-point Likert scale. The factors that influenced the study participants to attend the RWC

Table 2

Respondents' Region of Residence

\begin{tabular}{lc}
\hline Location & No. of Respondents $(N)$ \\
\hline Sydney Metropolitan & 295 \\
Europe & 38 \\
Other Australia & 138 \\
New Zealand & 14 \\
Asia & 11 \\
North America & 10 \\
South Africa & 3 \\
Argentina & 2 \\
Total & 511 \\
\hline
\end{tabular}


Table 3

Profile of Respondents

\begin{tabular}{lcc}
\hline Characteristic & $\begin{array}{c}\text { No. of } \\
\text { Respondents }(N)\end{array}$ & $\begin{array}{c}\text { Proportion of } \\
\text { Respondents (\%) }\end{array}$ \\
\hline Male & 375 & 73.4 \\
Female & 136 & 26.6 \\
Under 24 years old & 129 & 25.3 \\
25-44 years & 298 & 58.3 \\
45 yearst & 84 & 16.4 \\
Avid rugby fan & 155 & 30.4 \\
Frequent spectator & 127 & 24.8 \\
Casual spectator & 203 & 39.7 \\
Not a rugby fan & 26 & 5.1 \\
\hline
\end{tabular}

were first and foremost that it was a once in a lifetime opportunity (mean $=4.3$ ), an opportunity to cheer and support a team (mean $=4.2$ ), and to have a social experience $($ mean $=4.2)$. This was followed by being a big fan of RWC (mean $=3.9$ ), and availability of tickets, affordable, and "Sydney is safe" (all with mean $=3.5$ ). Of least importance was it being part of a holiday (mean $=2.9$ ) and for business networking $($ mean $=1.7)$.

Notably, only 11 of the 511 respondents indicated that they had considered not attending the game due to security reasons. A slightly higher number $(n=20)$ indicated that family or friends were concerned about their decision to attend the World Cup because of possible terrorist attacks. Feelings of safety during the RWC were high with $76.6 \%$ of respondents saying they felt either "very safe" or "safe." Results also indicated that the security measures slightly enhanced some attendees' level of enjoyment of the game $(23.8 \%)$, detracted from the event for a sample proportion $(1.9 \%)$, with the majority $(74.3 \%)$ stating that they were "neutral" about the impact of security on their enjoyment of the RWC.

\section{Factors Influencing Perceptions of Safety}

Place of residence emerged as a significant differentiator on perceptions of safety among event attendees. Sydney residents were less inclined to indicate that the security measures taken in relation to the RWC enhanced their perception of safety, compared with non-Sydney residents. Table 4 presents results of the residential dimension.

This could mean that local residents were slightly more sensitive about safety issues. This may be related to the media broadcasts about the level of security employed for the event coupled with headlines that the security measures were the most costly since the Sydney Olympics in 2000 . The local residents found the security at the stadiums more obvious than did nonlocals; however, they did not feel as safe as nonlocals. It is quite possible that the obviousness of the security, which was more rigorous than they usually experienced at the same venues, might have heightened their anticipation that a security problem was likely to happen, or may have created higher expectations with regard to security. A complementary explanation could be that visitors, already a self-selecting sample due to their decision to attend, upon spending the money, and effort traveling to the event, were less concerned about the obviousness of security because they were mentally captured by the media hype around the event and were engrossed in their RWC experience.

The size of the group attending the event with the respondent, or who they traveled with (i.e., solo, as a couple, organized tour, or with friends), had no relationship to feelings of safety at the RWC game or level of enjoyment of the game. The purpose of visit (i.e., to visit friends and relatives, for business, for the RWC experience) likewise did not

Table 4

Perceptions of Security by Place of Residence

\begin{tabular}{|c|c|c|c|c|c|c|}
\hline \multirow[b]{2}{*}{ Place of Residence } & \multicolumn{3}{|c|}{ Feeling of Safety } & \multicolumn{3}{|c|}{ Effect of Security on Enjoyment } \\
\hline & $\begin{array}{l}\text { Very Safe or } \\
\text { Safe }(\%)\end{array}$ & $\begin{array}{c}\text { Neither Safe } \\
\text { nor Unsafe (\%) }\end{array}$ & Unsafe (\%) & Enhanced $(\%)$ & No Impact $(\%)$ & Detracted $(\%)$ \\
\hline Sydney $(n=295)$ & 68.5 & 30.2 & 1.2 & 15.4 & 81.4 & 3.2 \\
\hline Other Australia $(n=138$ & 81.0 & 15.8 & 3.2 & 26.8 & 71.8 & 1.4 \\
\hline Overseas $(n=78)$ & 80.4 & 18.4 & 1.2 & 29.2 & 69.6 & 1.2 \\
\hline Total $(N=511)$ & 76.6 & 21.5 & 1.9 & 23.8 & 74.3 & 1.9 \\
\hline
\end{tabular}


produce any significant relationship to perception of safety.

Questions were asked about the obviousness of security measures in key locations, such as the airport, stadium, accommodation, transport, defense forces, and police. Respondents indicated that the number of these locations in which security was obvious was insignificant in enhancing their enjoyment during the game itself. Moreover, there was no relationship between "stadium security" and "higher level of enjoyment of the games."

Although the results indicate that if a spectator has a perception of feeling safe then they will also report enhanced enjoyment of the game, feeling of safety on its own was not a major factor in the person's enjoyment of the game. Rather, the function of the visit was the significant influencing factor on enjoyment. Spectators who attended the event for multiple reasons (e.g., once in a lifetime opportunity, cheering for your team, or socializing) reported the highest levels of enjoyment, regardless of their perceptions of safety or security.

Respondents were asked the following openended question: Do you have any suggestions or comments about security measures that might help the organizers of future large sporting events? Many respondents replied that they thought the security for this particular event was appropriate and should not be more overt than it was. However, other respondents felt that the bag searches were not done thoroughly enough and that the security in general was too relaxed. The top five suggestions for "best practice" were:

1. make security highly visible;

2. provide clear signage (and ensure signs are in other languages);

3. communicate security measures taken to the public;

4. ensure that safety protocols are taken seriously and not just there "for show";

5. provide enough event staff to enable smooth entry and exit at the stadium.

Respondents were also asked: Do you have any comments to make about the impact of terrorist activities on sport? The primary theme of these replies was that sport should not be affected by political terrorists, with comments such as "don't let them win- sport is above politics." There were indications from numerous attendees that they felt not coming to the RWC would be tantamount to giving in to terrorism. Furthermore, there was a strong sense of defiance among the respondents with many verbally commenting that their choice to attend was not going to be comprised by potential terrorist activity. One respondent even suggested that there was a positive to the increased security and that was that there were "more jobs are created due to increased security."

\section{Discussion}

Recent waves of insecurity and destabilizing developments have posed serious challenges in megasport event management. In the context of the "War on Terrorism" issues of security have come to the forefront in a range of areas, including the threat of a terrorist act occurring during a mega-sport event. This changed environmental context requires new kinds of understanding about sport event attendee perceptions, fears, and expectations. Other research has noted that the key to effective crisis management is in developing continuous learning processes designed to equip managers with the capability to deal with sudden and unexpected problems or shifts in public perceptions thereof (Robert \& Lajtha, 2002). By better understanding the perceptions of spectators about safety requirements and security needs organizers can work to ensure that appropriate actions are taken to satisfy these consumers. This is important for event tourism as terrorism is one of the most significant threats to tourism (Israeli \& Reichel, 2003).

This study outlined the extensive security and safety measures taken by event organizers at a recent mega-sport event, the 2003 Rugby World Cup (RWC). The comprehensive security provided for the event was deemed necessary because of terrorist activities closely preceding the event and perceived threat to Australia of retaliation for its subsequent military position. Data were collected on sport event attendees' perceptions of threats of terrorism, event security, and the nexus of these in relation to levels of enjoyment at the event. The attendees noted that the main reasons they came to the event was because it was a once in a lifetime opportunity, it provided an opportunity to cheer and support a team, and for the social experience. 
The survey results indicated that very few attendees had considered not attending the event due to concerns about terrorism. Security measures were perceived as adequate and the majority of attendees were neutral about the impact of increased security on their enjoyment of the event. Just over $23 \%$ indicated that the security actually enhanced their enjoyment and only a handful felt that enjoyment was negatively affected by the heightened security. Event attendees who indicate that they felt "very safe" reported higher levels of enjoyment than those attendees who merely felt "safe." Place of residence emerged as the most significant indicator of perceptions of safety among event attendees. Sydney residents felt that security measures taken in relation to the RWC did little to enhance their perception of safety, compared with non-Sydney residents. However, unlike Cashman's (2004) observations of the Athens Games, there was no indication of decreased crowds because of security threats at the RWC. Therefore, it could be suggested that the RWC organizers balanced security and enjoyment considerations effectively.

One key concern that emerged is the need to make the local attendees feel safe and improve their experience of the event. There is little doubt that the media play a role in disseminating key messages about the image and profile of events. Sport event managers would be well advised to work with the media to create an image that the rationale of security measures is to provide a safe and secure environment, and that the increased security is a proactive and a preventative measure, not one implemented as a response to intelligence reports suggesting that a terrorist attack is anticipated. These messages should be disseminated with particular focus on local residents.

The authors did not find any evidence to suggest that spectators stayed away from the RWC due to terrorism concerns. Given this finding it might be that Solberg and Preuss's (2005) contention that mega-sport event tourists will be deterred by terrorism concerns is not applicable to all sport event contexts. Because attending the RWC was considered to be a once in a lifetime experience and this was very important for the majority of respondents, their desire to attend may have overridden any concerns about safety. Notably, even those respondents who did not identify themselves as avid fans of the RWC, and those who were not regular rugby spectators, were relatively unconcerned about safety. This may suggest that the nature of the event-a large oneoff, multifaceted international experience-may be such that attendance motivation on its own overrides most concerns about safety.

It is noted that one of the limitations of the empirical component of this study relates to the respondent sample. We only surveyed event attendees, and not potential attendees. Therefore, there may have been people who did not come to the RWC due to concerns about safety. However, anecdotally, in conversations held with survey respondents, nobody could name or recall anyone they knew who did not come because of the security.

This study demonstrated that event attendees' motivation, expectations, and perceptions in relation to security and its impact on event attendance and enjoyment is an area for further research. The diverse attendees' profiles need to be better understood, not only to continue to attract attendees, but to be able to meet their distinct expectations through adequate provision of operational aspects such as safety and security services. Sport event managers need to balance the different needs of these spectators, the safety of the event, and ensure that the sport event experience lives up to spectators' expectations.

In rising to these challenges posed by the specter of terrorism it is possible that new and innovative ways of handling the situation will emerge. As Faulkner (2001, p. 137) noted, crises have transformational connotations and may lead to innovation and the recognition of additional markets. Also, by improving the management of sport events, there may be associated benefits. As was the case here, when security planning is managed in cooperation with the event organizers working with an existing range of relevant government authorities, there may be less costs accruing and fewer tensions arising from security issues. Finally, benefits beyond the event might be generated. The development of security protocols and process can be catalytic agents for greater cooperation between the state and sport organizations and hence even foster integration processes in economic- and security-related aspects.

\section{Biographical Notes}

Dr. Tracy Taylor has over 25 years of experience in the leisure field and has worked in various areas of public sector 
sport and recreation in both Canada and Australia. She is currently an Associate Dean in the Faculty of Business at the University of Technology, Sydney. Tracy is actively involved in research, consultancies, and community project work that encompasses dimensions of inclusively and diversity in sport. recreation, and leisure. Her research is mainly in the area of diversity and sport management, with a secondary interest in human resource management. Tracy is currently engaged in an ARC Linkage grant with the ARU on volunteer retention in community sport. Tracy also lectures and consults on leadership development and teambuilding.

Dr. Kristine Toohey is a Professor in the School of Tourism, Leisure and Sport Management at Griffith University located on the Gold Coast of Australia. She has operational experience in the field of sports management, event management, sport studies, and knowledge management. Kristine worked as a program manager at SOCOG, the Sydney Organizing Committee for the Olympic Games, between 1998 and 2001 , where she was in charge of communication services, a diverse operational unit within the organizing committee. She has acted as consultant to various organizations such as: The Olympic Co-ordination Authority, the Australian Sports Commission, the Australian Jockey Club, Womensport Australia and the Beijing Organizing Committee for the Olympic Games and the International Olympic Committee. She has published widely as the author or coauthor of a number of journal articles and books, most dealing with Olympic and sporting themes.

\section{References}

Australian Broadcasting Commission. (2003). Aust, England, US get extra Cup security. Retrieved May 24, 2004, from http://www.abc.net.au/sport/content/s962584.htm

Australian Department of Foreign Affairs and Trade. (2003). Advancing the national interest. Retrieved July 23, 2003, from http://www.dfat.gov.au/ani/index.html

Australian Department of Industry. Tourism and Resources. (2004). Economic impact of the Rugby World Cup 2003 on the Australian economy-post analysis. Canberra: URS Finance and Economics.

Australian Rugby Union. (2004). Annual report 2003.

Carey, J. (2004, January 5). Superdome, New Orleans step up security at game. USA Today, p. 5c.

Cashman, R. (2004). Athens 2004, the no-show Games. $\mathrm{Na}$ tional Forum. Online Opinion. Retrieved August 15, 2005 , from http://www.onlineopinion.com.au/view.asp? article $=2490$

Cavlek, N. (2002). Tour operators and destination safety. Annals of Tourism Research, 29(2), 478-496.

Coles, T. (2003). A local reading of a global disaster: Some lessons on tourism management from an Annus Horribilis in South West England. In C. Hall, D. Timothy, \& D. Duval (Eds.), Safety and security in tourism: Relationships, management and marketing (pp. 173-198).
Binghamton, NY: Haworth Hospitality Press.

Cronin, A. (2003). Behind the curve: Globalization and international terrorism. International Security, 27(3), 30 58.

Diaz, G. (2001, November 12). Olympics stress safety: Salf Lake City officials will re-evaluate the safety measures of the 2002 Olympic Games. The Orlando Sentinel, p. 1 .

Faulkner, B. (2001). Towards a framework for tourism disaster management. Tourism Management, 22, 135-147.

Faulkner, B., \& Raybould, M. (1995). Monitoring visitor expenditure associated with attendance at sporting events: An experimental assessment of the diary and recall methods. Festival Management \& Event Tourism, 3, 73-81.

Frosdick, S. (1997). Beyond football hooliganism. In S. Frosdick \& L. Walley (Eds.), Sport and safety management (pp. 3-10). Oxford: Butterworth Heinemann.

Gesterland, P., Gardner, R., Tsui, F., Espino, J., Rolfs, R., \& James, B. (2003). Automated syndromic surveillance for the 2002 Winter Olympics. Journal of the American Medical Informatics Association, IO(6), 547-554.

Goodrich, J. (2002). September 11, 2001 attack on America: A record of the immediate impacts and reactions in the USA travel and tourism industry. Tourism Management, $23,573-580$.

Israeli, A., \& Reichel, A. (2003). Hospitality crisis management practices: The Israeli case. International Journal of Hospitality Management, 22(1), 353-372.

Metcalfe, A. (2004, 23 March). Implementing a whole of government approach to national security and terrorism. National Security Australia. Retrieved February 17, 2005, from http://www.pmc.gov.au/speeches/metcalfe/ whole_govt_approach_2004-03-04.cfm

Pantera, M., Accorsi, R., Winter, C., Gobielle, R., Griveas, S., Queen, D., Insalaco, J., \& Domanoski, B. (2003). Best practices for game day security at athletic and sport venues. The Sport Journal, 6(4). Retrieved November 14, 2004, from http://www,thesportjournal.org/2003Journal/ Vol6-No4/security.asp

Pizam, A. (1999). A comprehensive approach to classifying acts of crime and violence at tourism destinations. Journal of Travel Research, 38(1), 5-12.

Pizam, A., \& Mansfeld, Y. (1996). Tourism, crime and international security issues. Chichester: John Wiley and Sons.

Richter, K., \& Waugh, W. (1986). Terrorism and tourism as logical companions. Tourism Management, 7(4), 230 238.

Ritchie, B., Mosedale, L., \& King, J. (2002). Profiling sport tourists: The case of super 12 rugby union in the ACT. Current Issues in Tourism, 5(1), 33-44.

Robert, B., \& Lajtha, C. (2002). A new approach to crisis management. Journal of Contingencies \& Crisis Management, 10(4), 181-191.

Ryan, C. (1993). Crime, violence, terrorism and tourism. An accidental or intrinsic relationship? Tourism Management, 14(3), 173-183.

Santana, G. (2003). Crisis management and tourism: Beyond the rhetoric. In C. Hall, D. Timothy, \& D. Duval (Eds.), Safety and security in tourism: Relationships, manage- 
ment and marketing (pp. 299-321). Binghamton, NY: Haworth Hospitality Press.

Snider, M. (2002). Safety in numbers. Maclean's, 115(6), 22.

Solberg, H., \& Preuss, H. (2005). Major sporting eventsare there any long-term tourism impacts? In J.Allen (Ed.), The impact of events (pp. 134-142). Sydney: Australian Centre for Event Management, University of Technology.

Tarlow, P. (2002). Event risk management and safery. New York: John Wiley and Sons.

Toohey, K., \& Taylor, T. (2005, July). The Olympics and terrorism. Paper presented at the Sporting Traditions Conference, Melbourne, Australia.

Toohey, K., Taylor, T., \& Lee, C. (2003). The FIFA World Cup 2002: The effects of terrorism on sport tourists. Journal of Sport Tourism, 8(3), 186-196.

Tsui, F., Espino, J., Dato, V., Gesterland, P., Hutman, J., \& Wagner, M. (2003). Data, network, and application: technical description of the Utah RODS Winter Olympic biosurveillance system. Journal of the American Medical Informatics Association, 10(5), 399-408.
United States General Accounting Office (2001). Olympic Games. Costs to plan and stage the Games in the United States. Report to the Ranking Minority Member, Subcommittee on the Legislative Branch, Committee on Appropriations, U.S. Senate.

United States Office of the Press Secretary, The White House. (2002, January 10). Preparing for the World: Homeland security and the Winter Olympics. Retrieved September 22, 2005, from http://www.whitehouse.gov/news/releases/2002/01/200201 10-7.html

Wedermeyer, B. (1999). Sport and terrorism. In J. Riordan \& A. Krüger (Eds.), The international politics of sport in the 20th century (pp. 217-231). New York: Routledge.

Wicks, B. (2002). World Cup fans: hooligans or tourists. In Proceedings of the Korean Academic Society of Tourism Management International Conference for the success of the 2002 World Cup (pp. 22-35). Korea: Korean Academic Society of Tourism Management.

Whisenant, W. A. (2003). Using biometrics for sport venue management in a post $9-11$ era. Facilities, $2 I(5 / 6), 134$ 141. 